FILOZOFIA

Roč. 76, 2021, č. 4

DOI: https://doi.org/10.31577/filozofia.2021.76.4.2

\title{
PROBLÉM ŽIVOTA ČISTÉHO JÁ V HUSSERLOVÝCH L-MANUSKRIPTECH
}

\author{
DAVID RYBÁK, Univerzita Karlova, Pedagogická fakulta, Praha, ČR
}

RYBÁK, D.: The Issue of Life of the Pure Ego in Husserl's L-Manuscripts

FILOZOFIA, 76, 2021, No 4, pp. $252-266$

In his Ideas Pertaining to a Pure Phenomenology and to a Phenomenological Philosophy, Edmund Husserl introduces the pure 'I' (reines Ich) as a peculiar, non-constituted transcendence that is not contained in the stream of immanent experience. In the Ideas, however, Husserl does not elaborate much on the consequences of this step regarding the internal time-consciousness. In this text, using Husserl's analyses in his so-called L-Manuscripts, we are trying to analyze the specific way of being of this pure 'I' in the light of this problem. The pure 'I' cannot be found in the stream of mental experiences, but leads egoic life as a subject in the form of 'being-present' (Dabeisein) for the series of these mental experiences.

Keywords: The pure 'I' - Life - Time-consciousness - L-Manuscripts

\section{Úvod}

Následující text si klade otázku po tom, co se proměňuje v Husserlově fenomenologii zavedením čistého Já pokud jde o problém toku védomí času a života tohoto Já. To, co je v tomto ohledu nové v projektu Ideji k čisté fenomenologii a fenomenologické filosofii, ${ }^{1}$ je zkoumání žijícího Já s jeho plným životem, s jeho habitualitami, afekcemi a akcemi. Zaměření předchozích fenomenologických analýz na prožitky a prožitkové souvislosti, $v$ nichž se konstituují předmětnosti vyššího řádu, bylo srozumitelné z Husserlova zaměření na problém základů logiky a vůbec problému poznání a vědy. V Idejích se pojem vědomí oproti předchozím projektům rozšiřuje, není již centrován v aktové, resp. noetické analýze, ale patří k němu celkovější souvislost života Já, která překračuje jednotlivé prožitky.

Problém žijícího čistého Já se týká nejhlubší vrstvy konstituce, totiž konstituce vnitřního vědomí času. Jak se mění problémová situace v této sfére po zavedení čistého Já? Zde nás Ideje I i II nechávají poněkud na holičkách. Ideje totiž

\footnotetext{
${ }^{1}$ Pracuji s českými překlady Husserl (2004; dále cituji jako Ideje I) a Husserl (2006; dále cituji jako Ideje II).
} 
programově nesestupují až ke konstituci vědomí času. ${ }^{2}$ Hlavní rovinou, na níž se pohybují, je transcendentální konstituce světa. Pro osvětlení problému čistého Já a vědomí času jsou cenné tzv. L-Manuskripty, ${ }^{3}$ zkoumání k vnitřnímu vědomí času, pocházející z let 1917 - 1918, a to zejména ty rukopisy, v nichž si Husserl vyjasňuje právě položenou otázku. ${ }^{4} \mathrm{~V}$ tomto ohledu představují L-manuskripty cenné docelení Idejí. Přesněji řečeno, jde o vzájemné doplňování obou textových celků. Nebot' v L-Manuskriptech je jáský pól sledován na abstraktivní rovině vztahu vůči časovému vědomí a hyletickému toku. Ale není postoupeno, jako se to děje v Idejích II, k plnému Já afekcí a akcí, Já monadickému, ${ }^{5}$ ani ke konstituci reálného personálního Já.

L-Manuskripty nesledují a nepředvádějí jednotné řešení, jde vlastně o sérii myšlenkových experimentů. $\mathrm{V}$ těchto experimentech Husserl testuje různé modely vědomí, pomocí nichž by bylo možné porozumět konstituci časového vědomí. Viděno z hlediska Husserlova vývoje, jde vlastně o prozkoumání možností a různých cest $\mathrm{v}$ problematice vědomí času, které jsou otevřeny projektem Idejí. Experimentální charakter L-Manuskriptů se ještě zesiluje tím, že žádný z vyzkoušených modelů časového vědomí nelze označit za plně uspokojující. Navíc samotný Husserlem použivaný pojem modelu se zdá být problematický. ${ }^{6}$ Pokud model chápeme jako hotové schéma, pomocí něhož se interpretují fenomény, neznamená to deformaci těchto fenoménů, které by přece měly být vyloženy ze sebe samých, a ne pomocí předem připravených interpretačních vzorců? V tomto př́spěvku nám nepůjde o samotné modely časového vědomí. Tato problematika již byla alespoň v hlavních rysech prozkoumána. ${ }^{7}$ Oproti tomu problém vztahu života čistého Já, toku vědomí a jednotlivých prožitků př́liš prozkoumán není. A právě ten nás bude zajímat.

\footnotetext{
${ }^{2}$ Srov. např́iklad: „Na tomto stupni úvahy, na který jsme vázáni až do doby dalších výzkumů a který se zř́iká sestupu do temných hlubin posledního vědomí, které konstituuje veškerou časovost prožitkü“ (Ideje I, 176[171]).

${ }^{3}$ Tyto rukopisy byly zpřístupněny pro fenomenologické bádání opožděně, nebot' až do roku 1969 je měl u sebe Eugen Fink (Rodemeyer 2005, 250). Název L-Manuskripty vychází ze signatury „L“, kterou jsou tyto rukopisy označeny v Lovaňském archívu. Byly vydány v roce 2001 jako 33. svazek edice Husserliana (Husserl 2001; dále cituji jako Hua 33.)

${ }^{4}$ Nám půjde především o dva rukopisy č. 14 a 15, obsažené v Hua 33.

${ }^{5}$ Zmíněnou abstraktivnost potvrzuje i to, že s pojmem monadického Já ani monády Husserl v L-Manuskriptech nepracuje, i když ho pro svou fenomenologii využívá již od roku 1905 (srov. Cristin 1990, 164).

${ }^{6}$ Podíváme-li se ze zpětného Husserlova pohledu, provizorní status $L$-Manuskriptů ohledně problematiky modelu časového vědomí potvrzují nepřímo též $C$-Manuskripty, které se odvolávají jako na východisko na rané časové analýzy (Husserl 2006a, 8). A ve zmínce o L-Manuskriptech jsou připomenuty nekonečné regresy, které se v nich Husserl snažil vyřešit (Husserl 2006a, 189).

${ }^{7} \mathrm{~K}$ diskuzi zmíněných modelů vědomí času viz Seel (2010). Ve smyslu nedořešenosti těchto modelů vyznívá i výklad Dana Zahaviho (2004). Zasazení do celkovější souvislosti časových analýz provádí Kortooms (2002).
} 


\section{Vědomí $a$ život jako fenomenologický problém}

Zdůrazněme hned ze začátku, že titul „život“ v souvislosti s fenomenologickými analýzami vnitřního časového vědomí neznamená žádný systém objektivních procesů v biologických organismech. Jde o strukturní souvislost v proudu vědomí, která je vykazatelná z čisté imanence tohoto proudu a událostí, které v něm probíhaji. ${ }^{8}$ Ve vyřazení objektivního času a v redukci na proud vědomí neprovádíme abstrakci na obecné pojmové jednoty. Nepohybujeme se v protikladu logických obecných forem a jednotlivin. Všechno bohatství zkušenosti zůstává zachováno, a to včetně čistého Já se souvislostí jeho života, s jeho přivraceními a odtaženími se $\mathrm{z}$ toku, s rozdíly jeho bdělosti a pozornosti, a také s jeho afektivitou.

Vyjdeme v našem výkladu z následující pasáže L-Manuskriptů: „Vědomí je životem a všechen život ve svých zvláštních životních pulzech je životem ve stravování života ${ }^{9}$ [Verleben], ve stálém uplývání života a všechen konkrétní život proudu života je jednotou vždycky nových životních pulzů, které samy opět „vystupují“ a „,zacházeji“", mizejí. Už v názorně dané dráze klesá živost, odeznívání je ještě během vlastního názorného odeznívání dozníváním, mizením, a je jím ještě potom, co už je plnost názornosti pryč." 10

Nejprve přičiňme obecnější poznámku. Posun v časových analýzách $L-M a$ nuskriptů spočívá, zpětně viděno, v tom, že zatímco v Logických zkoumáních a Přednáškách $k$ fenomenologii vnitřního časového vědomí dominovala noetická, aktová analýza, sledující akty udílení smyslu, Ideje přinášejí rozvinutí fenomenologie korelace noese-noema. Tím je otevřena cesta též $\mathrm{k}$ analýze noematických souvislostí. ${ }^{11}$ Proto je třeba upozornit na to, že pojmy „odeznívání“ (Abklingen) a „doznívání“ (Verklingen) či „zanořující se mizení“ (Dahinschwinden) nelze ztotožnit $\mathrm{s}$ tím, co známe z Přednášsk $k$ fenomenologii vnitřního časového vědomí jako retence. Modifikace, o kterých je v citovaném textu řeč, se týkají představujících obsahů toku, nikoliv retencionální formy, jakkoliv ta je $\mathrm{k}$ těmto obsahům korelativní.

Obtížnější je porozumět tomu, zda a v jakém smyslu je vědomí totožné se životem. Ve svých vyjádřeních Husserl často tuto identifikaci provádí. Proč je potom rozlišovat? Co má Husserl na mysli, když tvrdí totožnost „Vědomí je životem“? Je

\footnotetext{
${ }^{8}$ Zde se budeme soustředit především na problém vztahu čistého Já a toku. Co to konkrétně znamená „život“, jakou konstitutivní souvislost v časovém toku tento titul pojmenovává, viz Rybák (2021).

${ }^{9}$ Děkuji za tuto překladovou variantu Aleši Novákovi.

${ }^{10}$ Tamtéž.

${ }^{11}$ Srov. úvod vydavatelů L-Manuskriptů Berneta a Lohmara: „Manuskripty z Bernau rozvíjejí poprvé noematicky zaměřený popis vědomí času“ (Hua 33, xlv). (Tam, kde nemáme český či slovenský překlad, přičiňuji překlad svưj.) Tento postřeh, cenný pro porozumění celkového posunu Husserlova záběru, sledují de Warren $(2009,105)$ a Sivák (2016).
} 
vědomí životem ve všech ohledech? Nebo je život nějakým ohledem, nějakou strukturní souvislostí toku vědomí? I když, viděno z vyšších rovin konstituce, je život vědomí a tok vědomí totožný, takže Husserl oba aspekty často ztotožňuje, přesto jde na původní rovině časového vědomí o odlišné strukturní souvislosti. Připomeňme, že problém života jako specifické strukturní souvislosti proudu vědomí se nedatuje teprve od projektu Idejí, objevuje se již v textech kolem Přednášek kfenomenologii vnitřního časového vědomi.$^{12}$ Rozlišení tedy není konsekvencí zavedení čistého Já. Po Idejích se ale celá souvislost tímto obohacením o čisté Já komplikuje.

Vystihnout smysl identit a diferencí v toku je obtížné, nebot' v něm nemáme žádné věci o sobě a pro sebe. Intencionální vědomí je vědomím žijícího Já, a v tomto smyslu je každé ,vědomí něčeho“ žijící. Především na jednu stranu „vědomí"v tezích, ztotožňujících tok vědomí a život neznamená prostě „akt“, jednotlivý prožitek ve smyslu intencionálního vědomí něčeho jako něčeho. Ale na druhou stranu není vědomí od aktů odlišné. A to v tom smyslu, že se v aktech odehrává. Jednotlivé prožitky spolu s jejich noematickými obsahy přicházejí a odcházejí podle své časové formy, ale život nepřichází a neodchází ve stejném smyslu. Na rozdíl od jednotlivých prožitků, které mají svůj čas a odplývají v toku, pulzace života se svým zdrojovým Ted' se odehrává „vždy znovu“, aniž by šlo o pouhé opakování ve smyslu znovuzpř́itomnění, nebot' Ted' se jako Ted' nedá opakovat co do charakteru ,ted'kosti“, př́tomnosti. Ted' nelze opakovat, leda jako minulé Ted'.

Právě jsme použili termín „pulzace života“. Husserlova kardiologická metafora „pulzací či tepů umožňuje porozumět vnitřní strukturaci časového vědomí a jeho života. A to v tom smyslu, že není předpokládáno ideální homogenní kontinuum, do něhož jsou vloženy prožitkové mnohosti s jejich časovostí, ale samotná forma konstituujícího toku je rytmizována touto pulzací vzcházení jednotlivých Ted' a zase jejich odcházení. Zároveň je tato metafora problematická v tom, že využívá motivy časových souvislostí (pulzování, tepot, tikot) pro interpretaci konstituujícího toku, z něhož mají být časové souvislosti vyjasněny.

Termín pulzu či pulzu života (Lebenspuls) Husserl použivá i v jiných svých textech, aniž by ho nějak vyjasňoval. Díky L-Manuskriptům je souvislost, která je tímto termínem označena, poněkud jasnější. Spolu s odezníváním př́islušných prožitkových obsahů, resp. skrze toto kontinuum odeznívání prochází v toku ještě kontinuum modifikace intenzity, která je v kontinuu modifikaci odeznívání kontinuem snižování intenzity živosti př́slušného prožitku až od plnosti k nule (Hua 33, 69). Můžeme domyslet, že kdyby tomu tak nebylo, sice by odezníval př́islušný prožitkový obsah, ale

\footnotetext{
${ }^{12}$ Není zde prostoru pro to, zabývat se problematikou poměru života a vědomí času př̀ed Idejemi, proto pouze odkážeme na klíčové texty: v českém překladu srov. Husserl (1996, př́loha č. III k $\S$ 23), Husserl (2007, zejm. rukopis č. 46). A konečně Husserl (1980, text č. 7).
} 
nikoliv intenzita či živost jeho vědomí. Tato živost je živostí vědomí samého (Bewusstseinslebendigkeit), prožitkové obsahy mají své vlastní kontinuum odeznívání.

Shrňme rozdíl mezi prožitky a životem: čisté Já žije v jednotlivých prožitcích, $\mathrm{v}$ nichž se zaměřuje na něco jako něco. Není v nich ale většinou (pokud nejsme náhodou fenomenology) zaměřeno tematicky na celkový život imanentního vědomí času, na kontinuum, v němž se jednotlivá prožitková zaměření ve formě vjemů v imanentním čase odehrávají. Je zaměřeno na rozličná transcendentní témata ve světě. Život v jednotlivých intencionálních vztaženích není zaměřen jako téma. A přece o něm vím jako o souvislosti, která překračuje jednotlivé cogitationes, ale též ho netematicky, resp. před-tematicky žiji. Důležité je si uvědomit, že souvislost života nejen překračuje jednotlivé prožitky, ale není také totožná s konstitucí prožitkového kontinua. Patř́i k ní jednak intencionalita celku imanentního vědomí, jednak intencionalita rozhodnutí, habitualit, přání atd. s jejich koreláty, která se nekryje s tímto kontinuem, ale překračuje ho. Souvislost života zároveň otevírá problém způsobu jeho bytí, který se odlišuje od jsoucen konstituovaných ve světě. Život není mým výkonem ve smyslu aktivity: není tu Já, které je aktivní tak, že žije, že by žití bylo jeho aktivitou. Veškerá aktivita a afektivita Já se do souvislosti života vřazuje. Ale zároveň život není pouhá pasivita ve smyslu „se mnou se děje život“.

Život čistého Já tedy není totožný s jednotlivými prožitky, i když se v nich odehrává. Má jako specifická strukturní souvislost v toku celkovější dosah, ale ne ve smyslu pojmové jednoty, která by jednotlivé prožitky v sobě subsumovala jako své mody. Patř́i k němu struktura pulzování jako kontinuum živosti vědomí, proudící (strömend) v př́toku (Hinströmen) a odtoku (Verströmen) s centrováním v Ted’. Život svou pulzací konstituuje v souvislosti imanentního času vědomí specifické strukturní souvislosti, resp. právě tyto specifické strukturní souvislosti jsou živoucností, artikulovanou ve dvoutakt konstituujícího přítoku a konstituovaného odtoku. Tato strukturní souvislost proudění sama počíná „vždy znovu“, ${ }^{13}$ je novou, v Ted' centrovanou plností živosti. Ale zároveň každý nový prožitek se vřazuje jako událost do toku s retencionální minulostí toku a očekáváním. Jak myslet toto překročení jednotlivých prožitků?

Opět se nám vrací otázka po rozdílu vědomí jednotlivého prožitku a živoucího vědomí, tentokrát s ohledem na problém vřazení nových událostí do toku s jeho pořádkem. Nepředpokládá strukturní souvislost života opět vědomí, které není jednotlivým prožitkem? Jinak řečeno, $v$ jaké strukturní souvislosti jsou prožitky $v$ toku vřazovány? A na druhou stranu, vědomí je přece právě prožitkové vědomí, centrované

${ }^{13}$ Dáváme do uvozovek, nebot' čtenář musí mít na mysli, že tato charakteristika je vzata z již konstituovaných souvislostí zpř́ítomnění. Novost urimprese není vpravdě ani „vždy“, ani „znovu“. Jak víme, opakovat Ted' v jeho ted'kosti není možné. 
ve svém prožitkovém Ted'. Nějaké všeobecné vědomí, které by jednotlivé prožitky, a tedy jednotlivá Ted' přkekračovalo a shrnovalo, je v jednotlivých prožitcích, tj. právě v Ted' nevykazatelné.

A přesto nějaké takové vědomí tu musí být prostě proto, že jsme si vědomi nejenom jednotlivých prožitků, ale též časového pořádku jejich návaznosti, který tyto jednotlivé prožitky překračuje. Husserl sám si klade otázku po rozdílu mezi proudem s jeho fázemi a vědomím živoucího proudění: „Strukturu proudu podle jeho fází mám dánu, ale jak je to s vědomím živoucího proudění? Co se dá říci o tom?“ (Hua 33, 47) V odpovědi na tyto otázky mluví Husserl o „celkovém vědomí“ (Gesamtbewusstsein). ${ }^{14}$ Pokusme se tento motiv interpretovat z problémové souvislosti života.

Život ve své pulzaci není žádným objektivním či dokonce mechanickým procesem, sám je podobou souvislosti vědomí. „Pulz“ neoznačuje nějaký proces či systém procesů ve třetí osobě, ale samotnou živost vědomí v jeho rození, $v$ jeho vystupování (Auftreten) a zacházení (Vergehen). A to, jak už víme, v jeho prožitkové živosti. V rytmu pulzace se neustále rodí nové živé vědomí prožitkového Ted’s jeho dvojím uplýváním odeznívání představujícího obsahu a snižování živosti vědomí.

V celkové rytmice pulzování se rození vřazuje do již uplynulého. Pulz je rytmizován jako 1) souvislost rození nového Ted’s jeho živostí a 2) odplývání v podobě seberozestření v konstituovaném imanentním čase, opět př́ístupného v reflexi: „struktura života je tak uzpůsobena, že každý životní pulz sám podléhá zákonitosti proudu konstituujícího časovou předmětnost, tedy sám je znovu uchopitelný v reflexi“ (Hua 33, 168). K celkové struktuře života patří neustálé rození živosti nového, neopakovatelného vědomí Ted' $\mathrm{v}$ rytmice pulzování, ale zároveň $\mathrm{k}$ němu patří též konstituce rozestření tohoto vědomí v imanentním čase.

Všechny části a momenty toku jsou nesamostatné, resp. pouze relativně samostatné. Každá, do relativní samostatnosti vyzdvihnutelná část toku v sobě obsahuje překročení k minulému, zpětnou (Rück-) a dopřednou vztaženost (Vorbeziehung): „Ve změně intencionalit není celkové vědomí jenom v každém momentu stále nové, s novými intencionalitami, které mají zpětnou vztaženost ke starým a dopřednou vztaženost $\mathrm{k}$ novým, nýbrž zatímco přichází stále nové, zatímco proudí, mění se a mění se tak vědomí minulého a budoucího, je zde také vědomí o tom“ (Hua 33, $47-48$ ).

Celkové vědomí není tedy jakýmsi metafyzickým reliktem, nad-vědomím vně, nad časem toku, který pozoruje. Nic takového $\mathrm{v}$ toku nelze nalézt, a postulovat entity mimo tok by bylo v rozporu s fenomenologickým požadavkem př́sné deskripce.

14 Tento pojem, a to právě v souvislosti s motivem života, používá Husserl i v pozdějších zkoumáních. Srov. Husserl $(1968,44)$. 
V živé prrítomnosti, v živém Ted' máme dány též odkazy k uplynulému a očekávanému. A toto uplynulé a očekávané je zároveň uplynulým a očekávaným Ted', $\mathrm{v}$ němž je opět implikována nekonečná souvislost časových vztahů $\mathrm{k}$ uplynulému a očekávanému. A tak je v každém novém Ted' ve formě nekonečné odkazové souvislosti vědomo též proudění samo. Nebot' $\mathrm{v}$ každém novém Ted' nemáme jenom vědomí tohoto Ted' s jeho horizontem uplynulého a očekávaného, ale také odkazování na řadu vědomí časových vztahů k uplynulým a očekávaným: „Život sám je v toku živoucí vědomí toku“ (Hua 33, 103).

\section{Čisté Já a prožitkový proud}

Celá sledovaná souvislost života a prožitků, kterou jsme sledovali se dále komplikuje, vezmeme-li v úvahu čisté Já jako pól cogitationes: „... s tímto Ted' je zároveň odkázáno na subjektivitu, na Já, které má živoucí proudící život, ve kterém se Ted' může konstituovat“" (Hua 33, 135). Časový tok je tokem, v něm žije toto Já v médiu svých prožitků. Připomeňme, že žijící čisté Já, s nímž Husserl začíná pracovat zhruba od Idejí, nelze s tímto tokem vědomí plně ztotožnit: „... je třeba na jedné straně odlišit čisté Já od aktů samých jako to, co v nich působí a co se jimi vztahuje k objektům“ (Ideje II, 102[99]). A podobně jako jsme to viděli u souvislosti života a životních pulzů, ani čisté Já není totožné s prožitky: „Já je ,stojící a zůstávající Já, nevzniká a nezaniká jako prožitek. Není časově extendováno, není tedy v každé časové fázi jiné a není tím samým jako měnící jakožto proměňující se“ (Hua 33, 280). ${ }^{15}$

Tituly „Já“, „život"“, „tok“ atd. nejsou názvy oddělených věcí o sobě a pro sebe. V toku žádné takové věci o sobě nenalézáme - vždyt' smyslem reduktivních postupů je vyjasnění konstituce smyslu objektivity, a mimo jiné též objektivního času. ${ }^{16} \mathrm{Ve}$ svých popisech čistého Já a jeho života je Husserl věren svému principu všech principů. ${ }^{17}$ To znamená, že živoucí Já popisuje jako strukturní souvislost vykazatelnou $\mathrm{v}$ toku. Jen potud, pokud se souvislost života čistého Já rozestírá v konstituovaném toku, korelativnímu ke konstituujícímu vědomí, natolik je možné ho vykázat a natolik jest. ${ }^{18}$ Již při zavedení čistého Já v Idejích I Husserl upozorňuje na to, že „,[c]]isté Já chceme pokládat za fenomenologické datum, ale jen potud, kam až sahá bezprostřední evidentně stanovitelná osobitost podstaty a spoludanost s čistým vědomím, zatímco všechny nauky o něm, které tento rámec překračují, musí podléhat vyřazení“ (Ideje I, 118[110]). Přitom, ,jen potud“ tohoto metodického pravidla nelze

${ }^{15}$ Srov. Ideje II (105[103]): „Každé cogito se všemi svými součástmi vzniká a zaniká v plynutí prožitků. Avšak čistý subjekt nevzniká a nezaniká, ačkoli svým způsobem ,vystupuje ' a zase ,ustupuje “.”. ${ }^{16}$ Vyřazení objektivního času je iniciující reduktivní operací již v Husserl $(1996, \S 1)$.

${ }^{17}$ Srov. Ideje I (§ 24).

${ }^{18}$ Ve zkrácené Husserlově formulaci v L-Manuskriptech: „... smíme popisovat jenom tak, jak se v tom [toku] dává“ (Hua 33, 68). 
interpretovat tak, že bychom v toku nalézali jenom část čistého Já či jenom jeho jev. $\mathrm{V}$ takovém předpokladu bychom předpokládali transcendenci, která není nijak vykázána.

Čisté Já na jednu stranu není součástí toku, je funkčním pólem, který sám nepodléhá časovým modifikacím. Na druhou stranu ale není ani ničím o sobě a pro sebe někde mimo tok - je fungujícím pólem prožitků. Jak to Husserl vyjadřuje: „Tu je třeba na jedné straně odlišit čisté Já od aktů samých jako to, co v nich působí a co se jimi vztahuje k objektům; na druhé straně je takové rozlišení pouze abstraktivní. Je abstraktivní v tom, že Já není myslitelné jako něco odděleného od těchto prožitků, od svého ,života“, podobně jako tyto prožitky nejsou opačně myslitelné jinak než jako médium, jímž já žije“ (Ideje II, 102[99]).

Charakteristiky vztahu čistého Já a toku z předchozího odstavce se v hlavních momentech opakují i u pozdního Husserla. Jak je to ale s časovostí tohoto čistého Já? Připomeňme nejprve důležitý poznatek $\mathrm{z}$ analýz vnitřního časového vědomí, že konstituující tok není v čase, nemá ještě formu konstituovaného imanentního času $\mathrm{s}$ rigidním pořádkem časových míst. $\mathrm{K}$ této konstituci dochází až v sérii retencí a odeznívání prožitkových obsahů spolu s kontinuem živosti vědomí: „,... ne všechno subjektivní je časové, individuelní ${ }^{19}$ ve smyslu individualizovaného skrze jedinečné časové místo“ (Hua 33, 277). A stejně tak čisté Já jako pól prožitků není samo v čase, nemá časovou extenzi: „Co především nemáme v prožitkovém proudu, je Já samo, identické centrum, pól, na nějž je vztažen celkový obsah prožitkového proudu“ (Hua 33, 277).

Oproti dřívějším Husserlovým analýzám v Přednáškách k fenomenologii vnitřního časového vědomí, v nichž se objevuje idea kř́žení podélné a prř́čné intencionality, nebo obecněji trvání vědomí a vědomí trvání představuje krok zavedení čistého Já komplikaci celé souvislosti. Nejde již jen o vyřešení problému, jak je možné, aby ve vědomí času zde bylo též vědomí tohoto vědomí. Jde nyní též o to, jak myslet tok vědomí v souvislosti života čistého Já. A dále, jak z této souvislosti myslet to, že čisté Já žije v toku, ale zároveň není jeho obsahem.

V již zmíněných textech č. 14 a 15 L-Manuskriptů se dozvídáme, že čisté Já není v toku. Je „,nad“-časové (,,über“-zeitlich) či všečasové (allzeitlich) (Hua 33, 277 a 284). Všimněme si nejprve, že předponu „nad-“ používá Husserl v uvozovkách. Jaká výhrada je v tom naznačena? Husserl si uvědomuje, že titul „nadčasový“ (überzeitlich), který používal ve svých ranějších textech, nese s sebou význam věčnosti, která nebyla nikde $\mathrm{v}$ toku vykazatelná. ${ }^{20}$ Zároveň musíme tento charakter

${ }^{19}$ Ponechávám v překladu rozdíl mezi individuelním a individuálním, který odkazuje na rozdíl mezi reelním a reálným.

${ }^{20}$ K problematice termínů „všečasový“, „,nadčasový“, příp. „,nečasový““ srov. Derrida (2003, 66). 
„nad-“ či všečasovosti Já odlišit od všečasovosti ideálních předmětností jako je např́iklad ideální význam věty „kniha je zelená“ či platnost věty „trojúhelník má tři strany" ${ }^{21} \mathrm{~S}$ využitím Husserlova vyjádření můžeme říci, že pokud jde o Já, toto „nad-“ či „všečasové" neznamená idealitu předmětnosti, ale prostě to, že Já je identickým pólem pro všechny prožitky v toku vědomí, resp. pro všechny časové body (Zeitpunkte) a časové předměty (Hua 33, 279). Tak ř́ká Husserl, že Já není představovaným předmětem (Gegenstand), ale prastavem (Urstand) pro každou předmětnost (Hua 33, 277). Já tedy není vůči toku vědomí tak, že by bylo „nad“ ním a pozorovalo ho: „Nenalézám před sebou tok vědomí jednoduše tím způsobem, jako by ho Já jako čistě vnímající Já prostě uchopovalo“ (Hua 33, 283).22 Tomu již rozumíme: uchopování (Erfassung) ${ }^{23}$ se může dít teprve $\mathrm{v}$ toku. Já vůči prožitkovému toku nestojí v poměru intencionálního vědomí, ale života. V toku se odehrává veškeré ,být vědom něčeho jako něčeho".

Husserl ještě zesiluje v tom smyslu, že čisté Já by se vlastně ani nemělo nazývat „Já“, nebot' jakýkoliv název ho zpředmětňuje: „Já by se nemělo vlastně nazývat Já, ba vůbec by se nemělo pojmenovávat, protože tím už dochází $\mathrm{k}$ jeho zpředmětněni" (Hua 33, 277 - 278). Husserl pro ně používá poněkud novoplatónsky znějící charakteristiky „bezejmenné nad vším uchopitelným“ (Hua 33, 278). ${ }^{24}$ Toto paradoxní pojmenování nepojmenovatelného je srozumitelné z principielně reflexivní povahy fenomenologie. ${ }^{25}$ Prostá reflexe odhaluje již zpředmětněné obsahy toku. Je třeba následné reflexe, která reflektuje i na toto zpředmětnění. Jinak řečeno, pojmenování „Já“ předpokládá vždy reflexi, v níž je reflektovaný prožitek zpředmětněn, a tak je přehlédnuta jeho původnější, nereflektovaná povaha. Reflektující Já se vždy stává předmětně zaměřeným až v následné reflexi (Hua 33, 284). Husserl tak rozlišuje „Já jako všečasové individuum a jako sekundární časový předmět“ (Hua 33, 284). Aby nedošlo při řeči o sekundární předmětnosti k omylu, je zde důležité připomenout upozornění z Idejí II: „To, co se fenomenologicky obměňuje, když je Já předmětné nebo zase nepředmětné, není samotné Já, které uchopujeme a které je nám v reflexi dáno jako absolutně identické, nýbrž prožitek“ (Ideje II, 104[102]). Při reflexi jakéhokoliv stupně zůstává Já prožitkovým pólem, nikoliv obsahem. Před reflexí i po reflexi jde o tentýž pól Já, pouze jednou jeho danost není předmětná,

${ }^{21} \mathrm{~K}$ problematice časové formy ideálních předmětů v rámci L-Manuskriptů srov. Hua 33, text č. 18 a návazné př́lohy.

${ }^{22}$ A Husserl dále pokračuje: „Není na jedné straně proud a na druhé straně prázdné vidění proudu, nýbrž proudění a jednota proudu je intencionální jednotou sledu fenoménư“.

${ }^{23} \mathrm{~K}$ uchopování jako nejnižší formě jáské spontaneity viz Ideje II (37[23 - 24]).

24 Čtenáŕ si připomene metodicky rozvinutější a komplexnější pasáže (Husserl 1996, 208) o tom, že „Já“, získané pomocí epoché, je tak pojmenováno pouze ekvivokací.

${ }^{25} \mathrm{~K}$ tomu srov. Ideje I, zejm. § 77 . 
podruhé ano. Tak zároveň vidíme, že bezejmennost nemá sugerovat nepoznatelnost či metafyzickou nad-věc. Vždyt' tímto bezejmenným jsme my sami. ${ }^{26}$

Chybění pojmenování tedy není dáno nepoznatelností či nedosažitelností čistého Já, ale je srozumitelné z podstatné souvislosti konstituce a reflexe: víme již, že konstituujíci vědomí toku není ještě jsoucí, totiž individualizované skrze časová místa. Teprve v uplývání konstituujícího vědomí do minula se konstituuje pevná a v opakování identifikovatelná jsoucnost $\mathrm{v}$ imanentním čase $\mathrm{s}$ jeho pořádkem. ${ }^{27}$

V konstituujícím přítomnění není ještě žádná identifikovatelnost jako podmínka zpř́tomňování. To platí též pro bezejmenné „Já“. Toto bezejmenné není jsoucí, Husserl ho označuje jako „fungující“. Odkud o fungujícím Já víme? Zde je opět paradox: tímto (konstituujícím) vědomím jsme, ale tematicky o něm nevíme v jeho fungování, byt' jsme s jáským pólem našich aktivit a pasivit totožní. Je to např́klad moje vidění knihy, na které ted’ reflektuji, když ř́kám: „(já) vidím knihu“. Tato totožnost se ale ukazuje teprve v reflexi: „právě v reflexi bude [fungující Já] předmětné jako identické funkční centrum“ (Hua, 278). Tomu už rozumíme: Já je individualizováno teprve spolu s konstitucí prožitku s jeho časovými místy v toku.

Připomeňme, že již druhý díl Ideji II analyzuje čisté Já jako Já afekcí a akcí. Důležité je, že tyto afekce a akce nelze beze všeho ztotožnit s jednotlivými prožitky. Jak již víme, s problematikou čistého Já stojíme před celkovější problematikou jeho života $\mathrm{v}$ prožitkovém toku. Já není totožné se svými prožitky a s tokem vědomí. Jak víme z Idejí II, Já se chová k prožitkům v souvislosti svého života různými způsoby, jako aktivní či afektivní, přivrací se a odvrací či stahuje se z prožitků, ba dokonce nemusí vůbec vykonávat žádnou prožitkovou souvislost. ${ }^{28}$ Co se z Ideji II nedovídáme, je strukturní podoba těchto jáských akcí a afekcí ve vztahu k toku. I zde jsou L-Manuskripty poněkud sdílnější.

Dosavadní charakteristiky L-Manuskriptů je ale třeba ještě doplnit. Nebot' co je v L-Manuskriptech nové ve srovnání přinejmenším s prvním dílem Idejí, je prohloubení analýz ve směru genetické fenomenologie. ${ }^{29}$ Tok vědomí je strukturován,

${ }^{26}$ Můžeme opět připomenout explicitnější popis: „Vím přece ze svých fenomenologických studií, že já, bývalé naivní já, nebyl jsem nic jiného než transcendentální já v modu naivní skrytosti“ (Husserl 1996, 234).

${ }^{27}$ Ve svých pozdějších textech bude Husserl toto stávání se jsoucím označovat termínem „ontifikace“" (Ontifizierung).

${ }^{28}$ „V této souvislosti je důležité si povšimnout, že čisté Já není jen Já vykonávající, jak jsme je doposud výhradně zkoumali v určitých aktech, které se vyznačují formou ,cogito'. Podobně jako se okamžité cogito noří do inaktuality, v jistém smyslu se i čisté já noří do inaktuality. Stahuje se z daného aktu, již není v tomto aktu jako vykonávající Já a třeba už ani žádný akt neprovádí“ (Ideje II, $102[99-100])$.

${ }^{29} \mathrm{Na}$ to upozorňují ve svém úvodu Rudolf Bernet a Dieter Lohmar (Hua 33, xlv). K soustavnějšímu předvedení genetické fenomenologie lze čtenáři doporučit monografii významných fenomenologických badatelů: Bernet R., Kern, I., Marbach, E. (2004, zejm. kap. VII). 
jak to Husserl předvádí v L-Manuskriptech: ve 1) vrstvu nevědomých či před-vědomých afekcí a pudů, 2) vrstvu jáské polarizace, vědomého vztahování se k předmětům, 3) vrstvu duchovních aktů, nebo, jak to vyjadřuje Husserl, intellectus agens (Hua 33, 275 - 276). Tyto vrstvy neleží prostě nad sebou, ale nižší fundují vyšší a zpětně jsou zase vyššími oduševňovány. A především již vrstva před-vědomých či před-jáských afekcí v procesualitě života (Lebensprozess) obsahuje tendence k plné názorné danosti (Hua 33, xlvii). Vyšší vrstvy jsou s intencionalitou ve vlastním smyslu propojeny s nižšími ve specifické teleologii, která je ve statickém přístupu, sledujícím schéma fundace představa-soud-vůle, nepř́stupná. Viděno z této genetické souvislosti, ,„̌ivot“ neoznačuje pouze souvislost žití čistého Já v toku, ale zahrnuje též před-jáskou procesualitu afekcí a pudů, která je předpokladem jakékoli jáské aktivity. Přivrácení (Zuwendung) čistého Já k nějakému obsahu toku je možné jenom na základě afektivního vzbuzení zájmu v tomto Já, tedy na podkladě vrstvy před-vědomých afekcí a pudů. ${ }^{30}$

Afektivita je tedy primární, jáské akce mají tedy povahu re-akcí, předpokládají nějakou afekci toku. Já ve svém životě není sebekladoucí spontaneita, ani pouze registrátor toho, co se děje, ale aktivně i pasivně se na toku podílí. Jáské aktivity i pasivity jsou, jak říká Husserl, „totálně odlišným děním než všechno ostatní prožitkové děni'", nebot'v nich právě máme dáno př́slušné ,Já něco konám“ či ,se mnou se něco děje ' spolu s pólem Já, který sám není časový (Hua 33, 278). Jak to Husserl popisuje, Já je afikováno tokem a přivrací se $\mathrm{k}$ jeho obsahům. Při tomto přivrácení může reagovat na obsahy toku. Př́slušné přičiňování se na těchto obsazích má samo povahu prožitku (Hua 33, 279) a jako takové není sice uchopeno a spatřeno ( $g e$ merkt), ale je vědomo na způsob předreflexivní patrnosti (merklich) (Hua 33, 284).

$\mathrm{O}$ tom, že čisté Já samo sebe vnímá v reflexi, již byla řeč. Jak je to ale $\mathrm{s}$ touto reflexí samotnou? Husserl v L-Manuskriptech takto otázku neklade. Její rozvinutí na základě rukopisů nám ale pomůže lépe porozumět sledované souvislosti. Když charakterizuje vztah čistého Já k proudu života (Lebensstrom) a jeho obsahové mnohosti, říká Husserl, že spolu s hyletickými danostmi máme korelativně dáno Pra-Já $\left(U r\right.$-Ich) ${ }^{31}$ které ale nevstupuje do toku nahodile jako objektivní data, nýbrž je nutně přitom (dabei) jakožto jediný subjektový pól (Subjektpol) (Hua 33, 286). Já

\footnotetext{
${ }^{30}$ Srov. „korelátem pasivity afekce je aktivita přivrácení, pozornosti; a je-li Já pozorně při intencionálním předmětu, potřebuje afekci (která ovšem obecně vzato může být také funkcí názornosti a odeznívání), aby se neoslabilo“ (Hua 33, 68).

${ }^{31} \mathrm{~K}$ motivu Pra-Já a především jeho různým významům v Husserlově fenomenologii viz studii jednoho z vydavatelů L-Manuskriptů: Lohmar 2012. Pro potřebu naší studie postačí, když upozorníme na to, že předpona „pra-“ (Ur-) u Husserla indikuje nemodifikované východisko možných modifikací, v našem případě čisté Já jako pól před jakoukoliv reflexivní tematizací a před jakoukoli konkrétní akcí či afekcí.
} 
vstupuje do toku, jak Husserl ř́ká dále, jako ,živoucí zdrojový bod (der lebendige Quellpunkt) a tím živoucí bod bytí (Seinspunkt)“(Hua 33, 287). O tomto zdrojovém bodě Husserl říká, že „principiálně není př́ímo vnímatelný“, a teprve v následné reflexi je vnímatelný jako „hranice toho, co v časovém toku uplývá“ ${ }^{32}$ Tomu rozumíme tak, že i reflexe sama je časový prožitek. Není to jakési př́mé sebe-vnímání čistého Já jako pólu mimo prožitkový tok, ale vnímání čistého Já skrze prožitek. A to tak, že reflektuji na prožitek a v tomto prožitku nalézám jako pól Já. Proč živoucí zdrojový bod nelze vnímat př́mo, ale jedině v reflexi? Co se spolu s tímto „„ř́mo“"ztrácí?

$\mathrm{K}$ zodpovězení těchto otázek si musíme připomenout ještě jednou, že čisté Já jako pól je v poměru k proudu tak, že je nutně přitom (dabei) a propojit interpretačně toto zjištění s problematikou zdrojového bodu. Čisté Já není subjektovým pólem jaksi obecně, ale jeho ,bytí subjektem“ (Subjektsein) se odehrává právě jako přitomnost (Dabei-sein) pro prožitkové Ted’. Co potom není vnímatelné prrímo a co se $\mathrm{v}$ tomto smyslu v reflexi ztrácí, je právě tato při-tomnost. Nebot' stejně jako pro ted'kost i pro při-tomnost platí, že ji není možné opakovat, totiž jako při-tomnou. Co opakovat lze, a co je v tomto smyslu př́stupné následné reflexi, je tato při-tomnost jako uplynulá součást proudu života čistého Já.

Živá při-tomnost se nemodifikuje: čisté Já jako živý pól při-tomnosti se opakovat nedá. Víme již, že má všečasovou povahu, ale ne ve smyslu objektivní platnosti ideálních předmětností, které jsou platné v každém čase (i místě), nýbrž ve smyslu bytí-subjektem, ve smyslu pra-stavu pro prožitky. Totiž při-tomnosti, která na rozdíl od prožitků s jejich časovostí neuplývá do minula. V tomto smyslu ,bytí subjektem` (Subjektsein) čistého Já jako pólu se nevykazuje trvalostí na způsob věci trvající v čase. ${ }^{33}$ Není subjektem ve smyslu substrátu pro prožitkový tok, přetrvávajícího skrze jednotlivého prožitky jako své mody. Je subjektem ve smyslu subjektu života, který je ve všech svých prožitcích tak, že je při-tom. A toto ,být-přitom‘ je prastavem pro jakoukoliv prožitkovou souvislost v konstituci jejího časového rozestření. Husserl uzavírá své rukopisy o vztahu čistého Já a toku, resp. jáské a hyletické časovosti: „Já ale, které se takto vztahuje, je identické, v obsahu není nic identického. Říkáme, že Já žije svůj původní život tak, že v čase je stále se rozestírající prožívání se vždycky novým obsahem, ale tak, že to, co dává jednotu, je identické

\footnotetext{
${ }^{32}$ Tamt. Ve své interpretaci, vedené snahou ukázat př́buznost Husserlových časových analýz s Heideggerovými, upozorňuje Stolzenberg $(2017,167)$ na aristotelský základ tohoto konceptu hranice. I když to neupřesňuje, je zřejmé, že myslí na místo z Fyziky, kde se hovoří o to, že čas je ohraničen skrze Nyní (Aristotelés, 219a29). K Fenomenologickému prohloubení této souvislosti srov. Held (1992).

${ }^{33}$ Srov. „... o sobě je čisté Já neměnné. Není to cosi identického“ (Ideje II, 106[104]).
} 
bezobsažné - nikoliv substrát - nýbrž subjekt života, který se tak a tak vztahuje k objektům, k tomu, co je Já cizí، “34

\section{Závěr}

Viděli jsme v poslední citaci, že Husserl mluví o čistém Já jako identickém. To se zdá být v protikladu ke zdůrazňovanému charakteru Já jako pólu v Idejích II: , . . o sobě je čisté Já neměnné. Není to cosi identického“ “. ${ }^{35}$ Jde ale o dva různé ohledy: jednou o čisté Já jako bezobsažný pól („o sobě“), podruhé o Já, které žije ve svých aktech a konstituuje se jako identický vykonavatel těchto aktů, jako „stálé a trvalé“ (stehendes und bleibendes) Já. ${ }^{36}$ Identický tedy nikoliv ve smyslu v kontinuitě toku trvajícího substrátu, ale ve smyslu subjektu života, který se jako takový prožívá v živém Ted’. Rudimentární jádro této „identity“ jsme již sledovali v motivu „nad“-časovosti Já.

Tak se na závěr Husserlových analýz vztah čistého Já a toku odhaluje nová problematika, která je pro nasazení L-Manuskriptů, pohybujících se na abstraktivní rovině konstituce imanentního časového toku, viditelná jen zčásti. Husserl na této rovině neuvažuje o tom, že k životu čistého Já patř́ též typy intencionalit, jejichž platnost vykazuje jinou časovost, než je kontinuita imanentního toku. Sem patř́ intencionalita rozhodnutí, pasivních syntéz, habitualit, které vážou čisté Já k toku ve smyslu obsažné určenosti mající svou vlastní kontinuitu. Pojem habituality se v $L-M a$ nuskriptech neobjevuje. Poukažme zde pro stručnost pouze ke klíčovému $§ 29$ druhého svazku Idejí, v němž Husserl problematiku konstituce čistého Já jako jednoty ve vztahu k toku inaguruje. Problematika dějinnosti čistého Já jakožto Já afekcí a akcí nabývá na stále větší důležitosti v dalším rozvinutí genetických analýz. ${ }^{37}$

Analýzy L-Manuskriptů ukazují, že čisté Já nemá charakter obsahu toku, ani předmětného pólu, stojího ,proti‘ či ,před‘ tokem. Obě tyto alternativy vycházejí z časovosti konstituovaného imanentního toku, príípadně z ontické souvislosti světa předmětů. Husserl odhaluje čisté Já ve vztahu k toku jako ,prastav‘ (Urstand), jehož způsob bytí je srozumitelný z charakteru ,bytí-při-tom“ (Dabei-sein). Nemá charakter trvání v čase, nebot' živé Ted' jakožto Ted’ nelze opakovat. Živé Ted' nemá charakter matematického bodu, patří k němu pulzace konstituujícího a konstituovaného. Pro Husserlovu fenomenologii je tak charakteristické propojení života

\footnotetext{
${ }^{34}$ Hua $33(287-288)$.

${ }^{35}$ Děkuji recenzentovi dřivější verze tohoto textu, že poukázal na interpretační mezeru, která opomenula výroky sladit.

${ }^{36}$ Srov. Ideje II (113[113]) a Hua 33 (280).

${ }^{37} \mathrm{~K}$ rozvinutí časových analýz ve směru konstitutivního vztahu pasivně asociativních vrstev a čistého Já v genetických analýzách C-Manuskriptů jmenujme kromě již zmiňovaného Kortoomse (2002) z poslední doby syntetickou monografii J. Mensche (2010) a článek J. Brougha (2016).
} 
s problémem ,ted'kosti‘ (Jetzigkeit). V tom lze spatřovat její př́nos oproti myšlení, které naivně operuje s reprezentacemi ve smyslu objektivací, jejichž původ není vyjasněn. Ale též její hranice, nebot' tematickému projasnění vztahu života a smrti zůstal Husserl mnohé dlužen. ${ }^{38}$

\section{Literatura}

ARISTOTELÉS. (2010): Fyzika. Praha: Petr Rezek.

BENYOVSZKY, L. (2009): Proud živoucí přítomnosti a singulárně konkrétní subjektivita. K pozdnímu Husserlovu pokusu o temporální založení vazby člověka na svět. In: Kuneš, J., M. Vrabec: Člověk a jeho svět: filosofický pojem světa od novověku po dnešek. Praha: Filosofia, nakladatelství Filosofického ústavu AV ČR, 287 - 306.

BROUGH, J. B. (2016). Some Reflections on Time and the Ego in Husserl's Late Texts on TimeConsciousness. Quaestiones Disputatae, 7 (1), 89 - 108. DOI: https://doi.org/10.5840/ qd20167116

CRISTIN, R. (1990): Phänomenologie und Monadologie. Husserl und Leibniz. Studia Leibnitiana, $22,163-174$.

DERRIDA, J. (2003): Tradice vědy a skrývání smyslu. Praha: Oikúmené.

DODD, J. (2010): Death and Time in Husserl's C-Manuscripts. In: Lohmar, D., Yamaguchi, I.: On Time - New Contributions to the Husserlian Phenomenology of Time. Dordrecht - Heidelberg - London - New York: Springer, 51 - 70.

HELD, K (1992): Zeit als Zahl. Der pythagoreische Zug im Zeitverständnis der Antike. In: Blasche, S. - Köhler, W. R. - Kuhlmann, W. - Rohs, P. (eds.): Zeiterfahrung und Personalität. Frankfurt am Main: Suhrkamp, $13-33$.

HUSSERL, E. (1980): Phantasie, Bildbewusstsein, Erinnerung: zur Phänomenologie der Anschaulichen Vergegenwärtigungen: Texte aus dem Nachlass (1898 - 1925) (Skr. Hua 23). Haag: Nijhoff.

HUSSERL, E. (1968): Karteziánské meditace. Praha: Svoboda.

HUSSERL, E. (1996): Přednášky k fenomenologii vnitřniho časového vědomí. Rychnov nad Kněžnou: Ježek.

HUSSERL, E. (2001): Die Bernauer Manuskripte über das Zeitbewusstsein (1917/18) (Skr. Hua 33). Dordrecht: Kluwer.

HUSSERL, E. (2004): Ideje k čisté fenomenologii a fenomenologické filosofii I. Praha: Oikúmené.

HUSSERL, E. (2006): Ideje k čisté fenomenologii a fenomenologické filosofii II. Praha: Oikúmené.

HUSSERL, E. (2006a): Späte Texte über Zeitkonstitution (1929-1934): die C-Manuskripte (Skr. HUA-MAT 8). Dordrecht: Springer.

HUSSERL, E. (2007): Zur Phänomenologie des Inneren Zeitbewusstseins (1893 - 1917) (Skr. Hua 10). Dordrecht: Springer.

KORTOOMS, T. (2002): Phenomenology of Time. Edmund Husserl's Analysis of Time-Consciousness. Dordrecht: Kluwer.

LOHMAR, D. (2012): Ego and Arch-Ego in Husserlian Phenomenology. In: Breeur, R. - Melle, U. (eds.): Life, Subjectivity \& Art. Essays in Honor of Rudolf Bernet. Dordrecht: Springer.

MENSCH, J. R. (2010): Husserl's account of our consciousness of time. Milwaukee: Marquette University Press.

\footnotetext{
${ }^{38} \mathrm{~K}$ mezím Husserlovy fenomenologie živoucího Já, jak se ukazují z Heideggerova myšlení motivu čekání (Warten) srov. Benyovszky (2009). Z perspektivy pozdní Husserlovy fenomenologie ukazuje př́nos prozkoumání protikladu života a smrti Dodd (2010), a to v tom smyslu, že tento protiklad odhaluje celkovější souvislost nikoliv pouze mezi životem a jednotlivými prožitky, ale mezi životem jako celkem a tokem vědomí. Tato problematika ale přesahuje omezený prostor naší studie.
} 
RODEMEYER, L. M. (2005): “ Phenomenology of Time. Book review.” Husserl Studies, 21, 249 - 255. DOI: https://doi.org/10.1007/s10743-005-4938-x

RYBÁK, D. (2021): Problém života v Husserlových raných zkoumáních vnitřního vědomí času. Filosofický časopis, 69, 117 - 135. DOI: https://doi.org/10.46854/fc.2021.1r.117

SEEL, G. (2010): Husserls Probleme mit dem Zeitbewusstsein und warum er sie nicht löste. In: Frank, M. - Weidtmann, N. (eds.): Husserl und die Philosophie des Geistes. Berlin: Suhrkamp.

SIVÁK, J. (2016): K pojmu noematiky u Husserla. In: Javorská, A. - Kocinová, L. - Wagnerová, S (eds.): (Meta)filozofia - Prax. Bratislava: Slovenské filozofické združenie pri SAV, 137 - 143.

STOLZENBERG, J. (2017): Heidegger a Husserl o čase. Reflexe, 53, 157 - 159.

DOI: https://doi.org/10.14712/25337637.2018.9

Tento článek byl podpořen projektem PROGRES Q 17 - Příprava učitele a učitelská profese v kontextu vědy a výzkumu.

David Rybák

Univerzita Karlova

Pedagogická fakulta

M. D. Rettingové 8

11000 Praha

Česká republika

e-mail: david.rybak@pedf.cuni.cz

ORCID ID: https://orcid.org/0000-0003-0905-9327 